Article

\title{
Community Forest Management and the Emergence of Multi-Scale Governance Institutions: Lessons for REDD+ Development from Mexico, Brazil and Bolivia
}

\author{
Peter Cronkleton ${ }^{1} *$, David Barton Bray ${ }^{2}$ and Gabriel Medina ${ }^{3}$ \\ 1 Center for International Forestry Research, Av. La Molina 1895, La Molina, Lima, Peru \\ 2 Department of Earth \& Environment, Florida International University, Miami, FL 33199, USA; \\ E-Mail: brayd@fiu.edu
}

3 Setor de Desenvolvimento Rural, Escola de Agronomia, Universidade Federal de Goiás, Goiânia, Goiás, Brazil; E-Mail: gabriel.silva.medina@gmail.com

* Author to whom correspondence should be addressed; E-Mail: pcronkleton@cgiar.org; Tel.: +51-1-349-6017; Fax: 51-1-317-5326.

Received: 14 February 2011 / Accepted: 19 March 2011 / Published: 30 March 2011

\begin{abstract}
At their most local, initiatives to reduce emissions from deforestation and degradation (REDD) will depend on rural people to manage forest resources. Although the design of frameworks, mechanisms and arrangements to implement REDD programs have received significant attention, it is not yet clear how REDD+ will function on the ground or how the participation of local populations will be assured. Community forest management (CFM) could be an option under REDD+ depending on how it is negotiated, largely because of the expectation that CFM could reduce emissions from deforestation and degradation. Examining institutional factors in the emergence of successful CFM systems and local forest enterprises could provide valuable lessons for REDD planners. We examine cases of CFM development in Mexico, Brazil and Bolivia, to assess the role of multi-scaled governance institutions in their development. Comparing and contrasting advanced CFM systems to regions where it is still emerging, we will show how the establishment of a local organizational base for communal resource management is crucial.
\end{abstract}

Keywords: community forestry; REDD; governance institutions; Mexico; Brazil; Bolivia 


\section{Introduction}

One of the greatest challenges in designing REDD+ mechanisms will be determining what institutional design elements and implementation strategies will work best. In addition to current attention to international and national REDD architecture (for example [1,2]), there is a pressing need to focus on regional and local architecture, and to understand existing forest management strategies effective in stopping deforestation. Community forest management (CFM) is one proven strategy where collective action by local people can move beyond deforestation or degradation and achieve sustainable management, under certain conditions. Where successful, CFM is often associated with both secure rights to forest resources and the development of multi-scaled governance institutions [3-5]. Such institutions provide the legal frameworks that allow local people to establish control over forest resources and develop local-level governance structures adequate for new management demands. These local governance institutions can develop when supported to do so in alliances with networks of national and international government and civil society organizations. By comparing cases where successful CFM has emerged it will be possible to illustrate some of the local, national, and international institutional characteristics necessary for the development of governance institutions capable of maintaining forests, resisting deforestation and degradation and generating additional benefits. Examining the conditions that have enabled CFM development could provide useful lessons for REDD+ implementation.

There is growing evidence that varying forms of CFM have reduced, or stopped, deforestation and even enhanced carbon stocks under specific circumstances [6,7], and has done so while achieving more equitable outcomes in the distribution of forest incomes and at a relatively low cost [8,9]. The equitability and cost characteristics (and potential for joining development and conservation) makes CFM one REDD mechanism with great potential for adoption at the local level. A recent study found that the percentage of the global forest estate designated for use or owned by local communities and indigenous peoples went from $9.2 \%$ to $11.4 \%$ between 2002 and 2008 [10] and an earlier study found that $22 \%$ of developing country forests are in this category [11]. These numbers suggest a growing need to identify and maintain institutional frameworks to promote CFM. We argue that the global transition to CFM is central to achieving equity and the democratization of natural assets [12] while avoiding deforestation and degradation.

CFM in its various forms is particularly advanced in Latin America [13-15], likely associated with the relative degree of democracy in the region, which provides a context in which local governance institutions emerge and build multi-level linkages and alliances with other actors and organizations. As we will describe, some forests managed by communities, for the commercial production of timber, and occasionally non-timber forest products (NTFPs), have achieved what could be called a post-REDD landscape, i.e., where local-level decision makers over forests benefit by maintaining them, producing well conserved forest landscapes. Latin American experiences with CFM illustrate the importance of providing secure rights over forest property to community level actors and establishing conditions conducive to the formation of multi-scale governance institutions capable of maintaining and adapting forest management systems. Governance has been defined as "the traditions and institutions by which authority in a country is exercised" which suggests a focus on government and the relation between a government and its citizens [16]. However, scholars of forest governance have focused on the role of 
community-level institutions, which may or may not be part of recognized political authority in a country, and/or a broader set of relations between community institutions and government and NGO actors [17,18]. The concept of "multi-scale governance" is used here to include all levels and geographic scales of national and international government authority, local community governance regimes, and civil society institutional partnerships or networks which have decision making power or influence over forest management [3,5]. REDD+ faces a number of governance challenges. These include vertical and horizontal linkages between and among local communities, all levels of government, and civil society actors. There will be notable power asymmetries between many of these actors, and the processes will necessarily be turbulent [19], but government policy and international institutions can help strengthen the capacity of local communities to interact with other levels and develop multi-level collective action [17,20].

This paper analyses factors leading to the emergence of multi-scale governance institutions in CFM systems that successfully maintain forest landscapes drawing on cases from three Latin American countries: Mexico, which has a lengthy history of community management of forests and Brazil and Bolivia, two countries where innovative reforms have created conditions for nascent examples of CFM. A fourth relevant case, Guatemala, is not included for reasons of space [15]. The further challenge for these experiences will be how to extend the model into areas of currently threatened forests.

\section{Background: CFM and the Reduction of Emissions and Enhancement of Carbon Stocks}

It is not yet clear if REDD+ will systematically incorporate CFM as a central program component, although it has been proposed as an activity under REDD+ policies [21]. Community forestry can be broadly defined as the management of forest resources and services by self-defined communities or groups within communities under shared rules or collective rights. CFM takes many different forms across Latin America involving timber, non-timber forest products (NTFPs) and forest environmental services, with both subsistence and commercial production. This paper will focus on commercial timber management, since there is considerable emerging evidence that it can both conserve forests and provide major economic benefits to community groups [22]. The outcomes of CFM are shaped by forest type and size, resource quality and quantity, available technology, infrastructure and market access. How CFM emerges depends on these factors as well as local capacity and goals, opportunity created by legal frameworks, conditions supporting the formation of new local governance institutions and collaboration with other stakeholders at multiple scales.

REDD appeared as an official concept during the 2007 COP13 in Bali and the following year REDD+ emerged at COP14 in Poznan, inspired by concerns that focusing exclusively on deforestation and degradation could encourage bad behavior. It was proposed that the repertoire of activities for REDD should specifically include the "plus" of conservation, sustainable forest management, and enhancement of carbon stocks [21]. Although this would presumably include commercial timber production and indigenous/community conserved areas (I/CCAs), the extent to which these activities may be included in carbon stock enhancement under REDD+ is unclear [2], but it will certainly require local project-scale interventions [23]. Because much of the forest land in question is owned, occupied or used by rural people [10,24] whose livelihoods depend upon it, they must play a significant role in and be major beneficiaries of REDD+ programs. 
REDD + proposes to address deforestation and degradation through valuation of carbon capture, but to evaluate possible solutions, it is important to understand causes. The drivers of deforestation vary by world region and sub-region, represent different configurations of stakeholders, and have shifted over time [25,26]. For example, although small-scale farmers entering forests along logging routes contributed historically to deforestation in the Brazilian Amazon, they are not the primary drivers of deforestation. Remote sensing data now suggest that poor people are responsible for less than one-fifth of deforestation in the region. The lion's share is now driven by large and medium scale well-capitalized agribusiness on public lands [27]. The expansion into poorly controlled "open-access" public lands often displaced forest dependent people with more sustainable practices, due to the value of the forest soils for soybean production. Thus, efforts to implement REDD+ will have to engage medium-sized and large businesses and their sizeable opportunity costs. However, giving clear tenure rights to small-scale producers that occupy forests under pressure for conversion could help increase the value of standing forests for carbon.

Before the rise of the importance of carbon capture and other environmental services, strategies to stop deforestation and maintain forests have focused on three clusters of activities: (1) strict protection of forested areas, both public and private; (2) better management of production forests, whether public, private or communal and (3) regulation of land clearing in public and private forests [28]. Better management has included a growing emphasis on giving greater rights over forests to local communities that depend on them, within hierarchical or multi-scale frameworks of governance [3,27]. The tenure rights underlying community forestry can take a variety of forms and forest management may include a range of activities, from strict protection through subsistence uses to commercial production of timber and NTFPs. More recently, payments for environmental services (PES) have emerged as a new strategy to give value to standing forests [29]. These tenure forms and valuation strategies provide a toolkit of options which REDD strategists can draw upon. All tenure forms and strategies have had their share of both success and failure depending upon context. There are no panaceas [30]. However, protected areas, production forestry and PES all raise serious equity issues if they do not grant significant rights to local communities. There is a clear risk that REDD+ policies could recentralize forest governance, exclude communities, and weaken multi-scale governance [31].

Across Latin America, extensive areas of forest are already under the control of rural communities. In Mexico, two forms of common property, ejidos for mestizo peasants and comunidades for indigenous communities, now cover about half of the national territory. These communities have most ownership rights except alienation rights over some $60 \%$ of Mexican forests [32]. In Bolivia, communal indigenous property called Tierra Comunitaria de Origen (TCO) covers approximately 17.5 million ha in the lowlands with approximately 7 to 10 million ha under some type of forest cover [33]. Additionally, 2 million ha of forest land have been titled collectively to agro-extractive communities in Bolivia's northern Amazon [34]. In the Brazilian Amazon (480 million hectares), almost one-third of the region has been formalized under different property types for forest people, including $21 \%$ classified as indigenous territory, $6 \%$ as sustainable use conservation areas (including 48 Extractive Reserves covering 12 million hectares) and 5\% as other types of rural settlements [35]. The scale of these territories is impressive. However, there are also extensive areas of forest land in the region occupied by rural people but without formal rights and thus difficult to quantify. Often forest 
lands are nominally state owned but functionally open-access and susceptible to conflict, contested claims and deforestation.

Since REDD is primarily concerned with reducing deforestation, it is important to review the evidence that CFM has been able to reduce deforestation and degradation to date, without benefit of forest carbon valuation. Global evidence that CFM conserves forests, at least as well as protected areas, is emerging in large-scale comparative studies. A study of 163 forests in 13 countries found no differences in forest conditions between parks and forests controlled by local user groups [36]. As for the characteristics of CFM systems that achieve these goals most successfully, a study based on data from 80 community forests showed that communities with larger forests and greater autonomy have higher rates of carbon storage and livelihood benefits [6].

In Latin America, CFM, both for timber production and subsistence uses, has shown clear progress in reducing deforestation and conserving forests. In the Brazilian Amazon, both extractive reserves and indigenous territories, some of which are developing community logging, have been successful at reducing deforestation. The oldest extractive reserve in Brazil, Alto Juruá, established in 1990, still had over $99 \%$ forest cover in 2000, while income diversification improved the livelihoods of local people [37]. Indigenous territories in regions of frontier expansion have halted deforestation, despite high rates along their boundaries [7]. Modeling of scenarios in the Brazilian Amazon has shown that the extension of current forms of protection, including those that involve active participation by forest peoples in management (i.e., extractive reserves, indigenous territories, public forests), would reduce carbon emissions by more than half over a "business as usual" scenario [38]. In the Peruvian Amazon national parks along with indigenous territories and logging concessions have also reduced deforestation [39]. The Sierra Norte region of Oaxaca, Mexico, dominated by community management for commercial timber production, with recent diversification into ecotourism, water bottling and PES, has shown a $3.3 \%$ expansion of forest cover in its pine oak forests over a 20-year period [40], while other non-commercial types of forest have suffered high deforestation.

Co-management of protected areas by indigenous people, another form of CFM, can also reduce deforestation. Studies of the adjoining Rio Platano and Bosawas Biosphere reserves in Honduras and Nicaragua suggest that granting rights to indigenous people within the Bosawas Reserve has kept deforestation rates much lower than they are in adjoining mestizo areas in Nicaragua and in the Rio Platano Reserve, where no territorial rights were given [36,41,42]. Between 1995 and 2004, the rate of deforestation per capita in Bosawas' mestizo areas, under a private-property regime with no community management, was 16 times higher than in areas of the reserve under indigenous control [42]. In the Rio Platano reserve on the other hand, where indigenous peoples had not been given territorial rights, an advancing front of smallholders in one subregion deforested $12 \%$ of the area in only six years [41].

The evidence that community control and co-management can successfully maintain forest cover has increased interest in CFM as a potential REDD mechanism. Agrawal and Angelsen [43] have reviewed how CFM can contribute to REDD+ goals. Factors associated with successful CFM include functional communal resource management systems such as clearly defined boundaries and membership, equal opportunities to participate in the definition of rules, the capacity to monitor, and impose sanctions when infractions occur [44]. Other important factors include manageable group size — small to medium-sized groups — and group cohesion. 
In the next section we will examine three cases from Latin America where CFM for timber production in particular has emerged or is in the process of emerging. The cases focus on the most well known and extensive communal property types in each country: in Mexico comunidades and ejidos; in Brazil extractive reserves (RESEX); and in Bolivia indigenous properties known as TCOs. These cases will illustrate the role of forest tenure reform and multi-scale governance institutions in enabling CFM for timber.

\section{The Role of Tenure Reform and Multi-Scale Governance Institutions}

Throughout Latin America, due in part to grassroots movements that were required to assure full rights recognition, huge areas of forest lands have been devolved to local people in ways that create conditions for maintaining their forest livelihoods. Secure tenure is a key precondition for the successful implementation of REDD projects [45]. Secure tenure allows community-level actors the space and time to develop forest management systems [43,46,47]. It is a basic foundation that enables property owners to benefit from investment of labor and resources in management activities. It is also needed for accountability in financial transitions relating to carbon. When rights are not assured, local stakeholders are less likely to manage forests effectively or to develop necessary institutions that ensure ongoing forest stewardship. However, simply providing titles is not enough to assure that forests will be well-managed.

In Latin America, tenure reform has advanced to address property rights of forest people and has taken a diverse variety of forms to accommodate forest livelihoods [47,48]. When tenure reform creates enabling conditions that allow rural people to develop productive forest livelihoods, CFM systems are successful. Besides land tenure, successful CFM must include strong local governance institutions to regulate resource use, with the presence of legal frameworks, government programs and civil society organizations to help local communities link up with other institutional scales and negotiate with other stakeholders.

However, government policy makers often answer to competing interests and prioritize the demands of economically powerful actors and industries over those of communities. In response to power politics in the relatively democratic settings of Latin America, forest tenure reform and forest policies favorable to communities have frequently emerged in response to grassroots mobilization [49], resulting in a diversity of forms because of active local involvement in defining rights [47]. When grassroots activism shapes the types of rights granted, local rights are more likely to be respected.

The current landscape of community-controlled forestland emerged only after waves of grassroots resistance in response to national development policies. Although substantial areas of forestland are controlled by community-level stakeholders in the countries considered here, community control emerged from historical processes. In Mexico, community control has been a long-term process dating from the revolution early in the 20th century, however broad ownership rights have only been in place since a constitutional reform in 1992. Those reforms were preceded by grassroots mobilization for logging rights in various states in the early 1980s. In the Amazon regions of Brazil and Bolivia most rural people lacked legal forest property prior to the 1990s when reforms created new types of forest property and granted forest management rights. These reforms were responses, at least partially, to grassroots pressure from rural people struggling to maintain control over forest resources. 
In Mexico, the agrarian reform starting in the early 20th century created common properties and, mandated community governance institutions. As a result, by the time management rights were granted in the 1990s, Mexican communities, the government and civil society actors had several decades to test institutional arrangements and consolidate successful community forest enterprises (CFEs), particularly those with large forests (above 5,000 ha). In Brazil and Bolivia, property rights and forest management rights have been devolved more recently and almost simultaneously in each country. As we will discuss, the RESEX model in Brazil and the TCO model in Bolivia tend to have much larger territories, combine multiple communities and frequently have populations of mixed ethnicity or other sub-groups. Reforms did introduce some requirements for institutional governance but at the territorial scale, poorly linked to lower levels in these large properties. Local communities have confronted a complex process of adaptation to new property rights and have faced a steep learning curve in developing local governance institutions adequate for new production requirements, with inadequate legal frameworks to allow interaction with other levels and scales of governance.

\subsection{Mexico}

In Mexico, community forestry is rooted in the history of agrarian reform, arising from the Mexican Revolution of 1910-1917, subsequent land (and forest) redistribution and the decree of new agrarian governance institutions. Mexican agrarian law, established in Article 27 of the constitution, called for the implementation of two forms of common property, ejidos and comunidades. Land distribution process took place in waves, and as the 20th century progressed, the lands that were available for redistribution were increasingly in remote forested areas. Almost without design, the results of the reform process have placed some 60\% of Mexico's forest lands under communal property rights systems [32]. The legislation created community corporate entities with specific membership rules and governance systems organized around a territory. Given their legal foundation, mandated governance institutions, and linkage to community resource use, the communal properties created by the reform were rapidly consolidated and have remained relatively secure over time. Community property rights to forests were consolidated with the reform to Article 27 of the Mexican constitution in 1992 that removed language giving government "primordial" rights over forests [32]. Boundary disputes between communities are common but have generally not been a debilitating factor in promoting community forestry.

In Mexico, the democratization of natural assets [12] through the agrarian reform process laid the territorial and governance foundation for the establishment of a large community forest sector. It has been argued that a major factor in the success of Mexican CFEs was the universal community governance template established by agrarian law [32]. This template requires the formation of an Assembly of all legal community members, which elects for three-year terms a comisariado consisting of a President, Secretary, and Treasurer with a parallel three-member Oversight Committee. The common property form was based on indigenous concepts of communal property, but also introduced more formal notions of contemporary democracy with regular elections. The Assembly is required by law to meet twice yearly, but in well-functioning communities it is common to meet monthly or more frequently when events demand. This community governance template allowed for clear relationships between communities, their authorities, and all external actors. These governance institutions served as 
the foundation for the elaboration of more complex and innovative organizational forms required to administer more sophisticated and vertically integrated CFEs [32,50].

Despite this strong legal foundation, timber rights only emerged through a process of historical struggle. From the 1940s-1970s Mexican forest policy was based on logging concessions to outside contractors and logging bans. But in the mid 1970s, forest policy reform proposals began to emerge from a group of young forest policy makers, later joined by significant grassroots mobilizations in various states. Student activists in a few states also began organizing communities to establish their own forest enterprises [51]. The push to challenge the concession policy was spurred by the fact that logging concessions granted in the 1950s for 25-year periods were coming to an end by the early 1980s. With their concessions under pressure from community activism, the forest industries were forced to incorporate more community members into the productive process. This provided important human capital as the community members began to learn the basics of industrial logging skills and organizational forms.

The combination of grassroots pressure and legal maneuvering resulted in a Mexican court overturning the concessions in 1982, giving communities the right to manage their own forests for the first time, a right that quickly spread throughout Mexico in the 1980s [51]. Forest extraction and thus some management rights are now governed by the environmental laws of Mexico, but communities have all rights to forests except that of alienation of the forestland. It has been estimated that there are approximately 2,300 communities in Mexico with regulated logging, although many of these may only harvest occasionally due to small forest sizes. An estimated 599 communities in the ten most important forest states have achieved some degree of vertical integration, from owning skidders to sawmills and furniture factories, and another $640 \mathrm{log}$ regularly with outside contractors under management plans [52]. A significant number of forest communities, supported by legislation, are also organized into second-level or inter-community organizations, which allows them to hire their own forest technical assistance providers and collectively negotiate with the government and buyers. In recent years, Mexican government programs supported by the World Bank have sought to further strengthen the sector by providing technical assistance and international NGOs have supported certification processes. In a comparative study of 10 CFM experiences globally, Berkes [3] found that the Mexican CFE of San Juan Nuevo Parangaricutiro had the largest number of partners of any of the cases, from local to international scales. This suggests that the Mexican CFEs are embedded in wide-ranging governance partnerships. Such effective frameworks for multi-scale governance emerged from a combination of legally recognized local governance institutions, which are easily scaled up to regional and national confederations, a supportive legal framework, a history of supportive government programs, and, in some regions, the support of local, national and international NGOs. .

A good example of the emergence of a sophisticated, vertically integrated CFE within a framework of multi-scale governance in Mexico is seen in forest communities from the Sierra Norte of Oaxaca. The comunidad of Ixtlán de Juárez is composed of 384 legal members [53,54]. Since 1975, Ixtlán has developed a CFE with support from multiple stakeholders. The base of Ixtlán's community enterprises is 21,099 hectares of forests, with 13,577 hectares in pine and oak forests. Only 7,649 hectares are under more intensive commercial forest management. Ixtlán has also declared thousands of acres of tropical forest on the lower slopes as a community-protected area. Its forest operation has been certified by the Smartwood program of the Rainforest Alliance, an international NGO. Ixtlán's CFE 
employs up to 280 workers from both Ixtlán and surrounding towns, nearly 200 of them in their new industrial park. The community's sawmill was initially obtained from a government concessionaire, and has been managing successively more technologically sophisticated mills since the mid-1970s. Recently, increasing competitive pressures and the desire to expand employment opportunities has generated more ambitious business plans. With financing from state and federal government as well as community resources, Ixtlán has established an entrepreneurial alliance with other CFEs in Oaxaca. A joint venture between Ixtlán and two other Zapotec communities, Pueblos Mancomunados and Textitlán, has emerged instead of the more common mistrust and boundary disputes. The venture, called TIP Furniture ('TIP' for the first initials of the three partner communities), sells certified furniture from community forests. Launched in September, 2006, TIP now has three outlets in Oaxaca City. Such joint ventures have positioned these CFEs to meet the increasingly serious competitive challenge from Chinese furniture manufacturers.

Ixtlán and other similar communities have struggled over the years to adapt their legally-mandated community governance mechanisms to institutions that can be used to administer complex community enterprises. They have done this by developing new governance levels internal to the community, some with professional managers, but which still have to respond to the traditional elected representatives. Residents of Ixtlán have also developed significant capacity to establish partnerships and alliances with external actors. The community has a free-standing CFE that, with the exception of TIP furniture, is not part of any second-level or multi-community organization, as is the case with some Mexican CFEs. However, as noted above Ixtlán has benefitted from multiple partnerships and alliances with Mexican government agencies, state agencies, and both Mexican and international NGOs over the years.

Over the last decade, Ixtlán and other communities in the Sierra Norte have also diversified into community ecotourism, water-bottling, and more recently hydrological services. This suite of sustainable forest management activities, also pursued by other CFEs in the region, has resulted in the pine-oak forests of the Sierra Norte expanding 3.3\% over a twenty-year period. It is this kind of landscape, we argue, that can be considered a "post-REDD" landscape, what successful REDD projects will look like, and virtually without benefit of valuation of forest carbon.

The question for Mexico within the context of REDD+ is whether this model can be expanded to existing deforestation fronts. Recent figures on deforestation in Mexico by forest type show that forest loss is much reduced from previous periods, but particularly in all types of temperate forests. Deforestation is actually down in all forest types, but is now heavily concentrated in tropical forests, both humid and dry [55]. Most of Mexico's successful models of CFM for timber are in easier-to-manage temperate forests. However, there are also successful experiences in the more challenging tropical forests in the Yucatan Peninsula. In the tropical state of Quintana Roo, the 'Forest Pilot Plan' in the early 1980s was an institutional arrangement between state and federal governments and German bilateral assistance. This effort successfully helped to modify community governance to develop CFEs and promoted second-level organizations that could articulate effectively with actors at other scales, and stopped deforestation in the regions of central and southern Quintana Roo where it operated [56]. This general model could be revived with REDD+ funds. Dry tropical forests are an altogether different challenge, with their paucity of commercial species. However, there are also some 
successful models for using community conservation areas and the payment for hydrological services to protect dry tropical forests in Mexico [57,58] and these could be scaled up with REDD+ funds.

\subsection{Brazil}

Brazil's Amazon is a landscape of forest dependent communities and has been the focal point of efforts to promote CFM in the country. Amazon development policies up through the 1980s did not favor tenure rights or support forest livelihood activities of smallholders and communities occupying the region's forests. The shift to recognition of large communal forest properties occurred over time, partially in response to grassroots mobilization. One of the best known examples occurred in the 1980s with the attempted expulsion of rubber tapper families by cattle ranchers, a move supported by national and local governments. The conflicts over the control of forest lands sparked the rise of the National Rubber Tappers Council (known as the CNS, the Conselho Nacional de Seringueiros) made famous by their use of nonviolent collective action protests (empates) to halt deforestation and to draw attention to the plight of families pushed off their land. The CNS also formed alliances with other forest peoples and international environmental NGOs to pressure the Brazilian government to respect the property rights for forest-dependent people [59,60]. One result was the definition of a new communal property type, the extractive reserve (RESEX). RESEX are conservation areas that allow forest inhabitants to continue occupying the land and practicing their traditional way of life and culture, mostly based on NTFP extraction [61]. Currently in the Amazon there are 48 RESEX covering a total of 12 million hectares [35], mostly tropical forests that had previously been threatened by external actors bent on forest conversion or engaged in unsustainable extractive practices. Subsequent to the creation of the RESEX model, Brazil has gone on to create a variety of conservation areas administered by the Environment Ministry (MMA) through the Instituto Chico Mendes de Conservação da Biodiversidade (ICMBio) and different colonization settlements schemes, administered by the Agrarian Development Ministry (MDA) through the Instituto de Colonização $e$ Reforma Agrária (INCRA) that accommodate the livelihoods needs of forest dependent people in rural communities. Nonetheless, it is estimated that there are still about 296 thousand families in the Brazilian Amazon living under informal land tenure regime (posseiros).

Although the RESEX model responded to livelihoods demands of forest people, they were also located in conservation areas so management rights were restricted. Regulations allowed residents to maintain traditional livelihoods activities, particularly extractive NTFP collection, but technically they were required to develop a management plan for the entire RESEX. The demarcation of huge areas as RESEX that encompassed multiple communities has meant that residents have to develop new governance institutions while attempting to adapt forest management rules to the new landholdings. Resource use decisions in the RESEX that had taken place at the community level are now controlled at the territorial scale, far removed from the local communities. Residents were required to form a management council for the RESEX (Conselho Gestor da Resex) composed of representatives of community organizations as well as other local stakeholders and headed by ICMBio.

In the 1990s, there was increased interest in reform to encourage residents of Brazil's forest properties to become more active participants in communal forest management, primarily through commercial exploitation of timber. However, integrating communities into the timber sector has not 
been easy. The 1965 Brazilian forestry code (Código Florestal Brasileiro) was geared primarily to the needs of large scale timber industry and acted as a barrier to other forest stakeholders.

In 1996, an extensive effort to promote logging by communities was undertaken by the ProManejo program (Projeto de Apoio ao Manejo Florestal Sustentável na Amazônia). ProManejo financed 24 pilot forest management initiatives for small-scale producers scattered across the region. The NGOs and agencies implementing the pilots focused mainly on training communities in reduced impact logging and assumed the responsibility for establishing market chains for communities' timber, often focusing on market niches, and navigating through the bureaucratic approval process. Many of these initiatives were heavily subsidized with investments ranging from approximately US $\$ 19$ thousand to over US $\$ 700$ thousand per community [62]. Although community members participated in some activities, the conception and definition of the management approach were generally controlled by the external development technicians. Because they depended on subsidies and unfamiliar concepts, the CFM models being tested were not adopted by neighboring communities and collapsed once external support was removed [63].

The Brazilian forestry law was reformed in 1998 to create a category for community timber management and was modified again in 2006 to create simplified management plans for communities with low intensity operations. Despite efforts to simplify the legal framework, communities still face challenges in preparing formal management plans and participating legally in commercial timber management, often because the technical and bureaucratic requirements are still above the administrative and financial capacities of communities. As a result, most rural people who commercialize timber remain in the informal sector logging illegally.

One example is the case of traditional rural communities in the municipality of Porto de Moz in the State of Pará. Porto de Moz residents have struggled to defend their lands and forest livelihoods from external competition, initially to resist invading fishermen in the 1980s, and later in 1996, to defend against invasion by logging companies. Residents formed the Committee for Sustainable Development of Porto de Moz, a second-level organization or network of existing local organizations such as community associations and the Rural Workers Union, thus creating a new level of governance through grassroots action. It was through this committee that some communities demarcated community areas (approximately 10,000 hectares each) and demanded land tenure rights. However, their tenure demands received little attention from the government. The communities, supported by an influential international environmental NGO, reformulated their embryonic concept of community areas and demanded the creation of a RESEX. Only through alliances with powerful external players were communities' demands acknowledged. Such alliances have provided access to government agencies and, in some cases, drew national and international attention to the plight of these communities. As a result, the largest extractive reserve in Brazil, called Verde para Sempre (Forever Green), was created in 2004. The RESEX covers 1,288,000 ha, representing $74 \%$ of the municipality, and includes 180 individual forest communities.

Living in a conservation area, the residents face new challenges in developing an effective model of multi-scale governance and forest management, particularly for timber. Commercial logging companies are now legally excluded, and all commercial logging is officially banned until a management plan for the RESEX has been formulated. Families continue extracting sawed timber as one of their main sources of income, but the management is informal and they are forced to operate 
clandestinely. Officially, these problems could be resolved by the development of a RESEX management plan but Verde para Sempre only has a transitory plan with broadly defined guidelines (and in fact, most of the RESEX in Brazil still do not have management plans). The RESEX management council is supposed to approve the content of the management plan with financing by the ICMBio. The communities' representative organisations faced a new challenge in the council because it also included representatives of private and urban sectors. Important decisions are now made by people outside the communities, such as government agencies that are on the council, and community groups struggle to maintain the greatest possible representation on the council and attempt to keep groups representing the interests of loggers and ranchers from gaining control.

Families in Verde para Sempre are now attempting to organize a local governance system for extracting forest products based on their earlier community level arrangements and are negotiating to gain recognition from the government. Unlike Mexico, there is no legally recognized community level governance institution. In the search for clearer timber rights, residents propose formalization of the low intensity logging they had been practicing informally at the community scale. The communities are defining alternative forest management systems based on local norms to regulate access and use of forest products within their area. They are trying to negotiate and receive assistance from official agencies and NGOs, a process evolving towards a clearer framework of multi-scale governance. Families expect that by documenting their system, they can convince the government to officially acknowledge it and, as a result, they will sell legalized timber and get better market prices. The government is interested in negotiating with the communities to develop a decentralized governance system capable of administering such an enormous territory with dozens of communities. Negotiations are ongoing but it is hoped that adapting CFM to the scale of existing community institutions will provide greater local control.

One of these systems is being developed for local families involved in a traditional boat building industry that has existed informally for generations. In the RESEX there are about 30 families that participate in the boat building trade spread across 10 communities. Local artisans were concerned that two of the main timber species they used were becoming increasingly rare. The proposal focuses on improvements to local boatyards where construction takes place and definition of specific areas where timber can be harvested. The boat building families are negotiating with logging families to define norms of access and use based on local capacities that can lead to sustainable management practices. Similarly, in communities where sawyers had harvested wood clandestinely, mostly targeting local and regional markets for fence posts and construction, the government and residents are discussing the establishment of accountable local governance systems. Community residents are motivated by the belief that through formalization they could get better prices and it would be less risky arranging sales. The government is interested in promoting more sustainable practices and avoiding resource conflicts; as a result, it is working with locals to develop viable agreements to establish a monitoring system for local social control.

Engagement with community level organizations is a promising strategy for strengthening local level governance within the RESEX, particularly if mechanisms for formalizing the role of these groups result and they can be linked to other levels of governance at the RESEX, municipal and regional scales. Without a process for developing legal options for resource use, residents would otherwise continue informal practices, and the lack of coordination could potentially degrade forests in 
the RESEX. Although the context within extractive reserves is distinct from the open or contested access rights found on other deforestation fronts in the Amazon where REDD+ programs may be focused, experiences like those of the residents of Verde para Sempre could provide examples for innovative strategies to strengthen community level governance institutions elsewhere.

\subsection{Bolivia}

In Bolivia, CFM rose to greater prominence as a series of tenure and forest policy reforms took place in the 1990s. Prior to 1996, forest-dependent people in Bolivia's lowlands did not have secure property rights or legal options for forest management. Although there had been colonization programs and efforts to regularize the property rights of smallholders (particularly migrants), tenure rights were limited to 50 hectare plots for swidden agriculture [64,65]. Legal rights to exploit forest resources were extended to a few large forest industries. A key factor in changing this situation was grassroots activism which pressured the government to grant property rights over traditional territories and corresponding legal rights to manage forest resources. The lowland indigenous federation, Confederation of Indigenous People of Eastern Bolivia (CIDOB), was a main protagonist in marches on the capital to push the central government to recognize the territorial demands of indigenous people. Bowing to growing pressure, the government enacted a series of presidential decrees defining a type of property known as a Tierra Comunitaria de Origen (TCO), later formalized with the passage of a tenure reform law known as the INRA law in 1996. TCOs are properties based on ancestral claims and territorial needs assessments that consider livelihood characteristics and the potential for growth in the indigenous population.

The INRA law established a process that allowed indigenous groups to petition for property rights as TCOs and initiate titling. In the forested lowlands 60 TCO demands were submitted to the government for more than 17.5 million hectares, with an average property request covering approximately 200,000 hectares. Titling has proven to be a long and drawn out process. Ten years after the passage of the INRA Law, only 30 TCOs are at least partially titled. The titled area accounts for only $49 \%$ of the 9.6 million ha demanded by the lowland TCOs [66]. Although the government halted new competing claims, in practice indigenous residents have had to struggle to maintain control over their territorial demands while property claims of third parties to the territory are examined. Given these complications, communities turned to formal forest management plans as a means of consolidating property rights claims within their TCO demands.

Bolivia's 1996 Forestry Law recognized the exclusive rights of property owners to manage forests on their land. This included TCO residents who could practice subsistence management using customary practices (usos y costumbres) or commercial management under a management plan. The law defined technical norms for timber management plans in TCOs, and although the complexity and cost of developing a plan required assistance from NGOs or industry, some communities adopted commercial forest management as a strategy to demonstrate their forest use and land occupancy. Since the passage of the forestry law, CFM has expanded. As of 2006, 88 indigenous community forestry enterprises (CFEs) had been initiated in the country, 48 with approved management plans encompassing an area of 1,345,767 ha [14]. These groups appeared at the same time that property rights were being consolidated. 
In Bolivia, CFM for timber has played an important role in assisting indigenous people to consolidate their hold over forests and to defend them against other interests while the TCO demands are titled. Property rights and forest management rights were granted at roughly the same time. Resident families in the new properties have had to develop governance institutions that conform to the new rights allocation. Once TCO demands were accepted, territorial organizations were ill prepared to take over formal administration and governance of the huge properties. As in the Brazilian RESEX, many TCOs comprise multiple communities and villages, sometimes with distinct ethnicities, with little tradition of coordination above the village level. The political organizations representing TCOs typically have little experience in representative democratic decision-making, leading to weak communication with village-level constituents and little transparency. Besides territorial administration, local authorities became responsible for overseeing the TCO titling process and for negotiating amongst competing interest groups.

A good example of this process can be seen in the Guarayos TCO in the department of Santa Cruz. The TCO was created in 1999 for a 1,349,882 hectare property, with the title issued in the name of the indigenous organization COPNAG (Central de Organizaciones de Pueblos Nativos Guarayos). When the demand was submitted the population in the area was just over 31,000 people scattered between six towns and 12 villages, although not all were Guarayo [34]. The INRA law stated internal governance would be based on 'usos y costumbres' but did not specify how this would be carried out. The Guarayo traditional system is based on the concept of zonas agrarias, agricultural zones in which agriculture lands are distributed to families as individual plots surrounded by larger belts of communally-accessed forest. Small villages are organized as single zones, while larger towns could have dozens of zones. Rather than focus titling efforts on the indigenous units represented by the agricultural zones, the government instead started titling remote uncontested areas in the TCO, while populated areas where indigenous rights were most threatened received less attention initially [34]. In response to the delay in the titling of their lands, communities turned to CFM strategies to defend village territory and by 2004 six Guarayos communities initiated forest management plans covering 151,178 ha [34].

One of the more successful cases of CFM in Guarayos is the community of Cururú. Cururú is a small remote village, which had fewer than 30 families when the TCO was formed. They had no previous experience administering logging operations, but their forests had been logged by timber companies prior to the new forestry law, which gave them some understanding of logging operations. In 1999, the community began developing a forest management plan and residents formed a management organization called the Asociación Indígena Maderera Cururú (AIMCU). Cururú's residents received technical and financial assistance from the USAID-funded forestry development project, BOLFOR, and other NGOs to begin developing a forest management plan, which covered 26,420 ha of forest around their village. The plan was approved by the government in 2002.

Given their lack of experience, operating capital and machinery, the community decided to sell standing trees during the first years. Assisted by NGO technicians, they negotiated with local loggers and reached an agreement in which the community made 'in-kind' payments of certain timber species to a local company that provided services to fell, yard and transport, their timber to buyers. In subsequent years, the community took control of the tree felling and thus generated additional wage labor for residents. However, they remained reliant on service providers and NGOs. In 2007, their management operation received Forest Stewardship Council certification which allowed AIMCU to 
develop partnerships with certified industrial concessionaires in Guarayos, ensuring more dependable markets [34]. Ironically, one of Cururú's advantages was probably its remote location. Although its location raised the cost and complexity of their operation, it lowered pressure from outsiders trying to claim forest lands during the titling process. The families had several years to gain experience and learn which allowed them to consolidate their management organization and control their territory, thereby defending it from other actors moving into the region.

CFM emerged in TCOs to establish control over traditionally used forests. Cohesive communities were able to work collectively to defend their interests over surrounding forests, and the development of a forest management plan provided a framework to represent their claims and demonstrate resource use. Formal CFM still remains the exception for most indigenous communities and TCOs lack mechanisms for developing or strengthening the fine grained governance institutions that should function at the local level. CFM organizations have begun to fill that void, but usually when they have received external assistance. Where TCO residents are under less pressure and have time, forestry initiatives could help them develop stronger governance institutions based on traditional usos $y$ costumbres within their TCO. However, the promotion of templates for governance institutions that are linked to resource management developed in coordination with indigenous people, much like those present in the Mexican case, could play a central role in REDD+ programs that rely on CFM models, and would further support improved internal governance of TCOs and assure that residents benefit from forest resources.

\section{Creating the Conditions for CFM as a REDD+ Strategy}

REDD+ outcomes could be achieved through the adoption of CFM. Achieving the desired outcomes would depend on the creation of conditions that are conducive to successful CFM. These conditions begin with secure property rights over forest resources, including timber, and then progress towards strong governance institutions adapted to local context and linked to multiple scales that enable sustainable management. REDD+ planners face a challenge in determining how to design systems supportive to the emergence of such governance systems. The examples presented in this paper illustrate how local community level stakeholders can play proactive roles in defending their livelihoods interests to assure that forests are placed under community control, however without efforts by national government actors, civil society, and international institutions that support the emergence of strong multi-scaled resource governance institutions, they will not necessarily be successful.

The examples presented in this paper represent a diverse spectrum in the development of local forestry institutions. Mexico's CFM success is due in large part to an agrarian reform, which established a precedent for devolving communal property rights over significant portions of the country's forests, and which also introduced an institutional template of legally recognized community governance. By contrast, in Brazil and Bolivia, extractivist and indigenous communities have been remarkably successful in winning recognition of their property rights over immense territories, but in many cases they have struggled to develop local and territorial management institutions capable of overseeing vast multi-community territories, and that can link effectively with other actors. As a result, the RESEX and TCO models can create governance vacuums where local level institutions are not empowered but are instead replaced by official territorial or regional organizations that are granted 
powers but are weak and have tenuous linkages with local level where resource use decisions (and conflicts) take place.

In the Mexican case, multi-scaled governance is well developed among some comunidades and ejidos. These groups have benefited from relatively secure tenure, usually in properties scaled to the needs of single community groups, and from the introduction of a governance template that structured the types of local institutions that were officially sanctioned by the state. The agrarian law required the creation of two parallel governance bodies for administrating the individual community properties. These institutions have clearly defined membership, specifically defined roles and basic rules for their operation. They were tied into broader governance structures, but also, over time, these organizations gained experience and matured so that they developed greater capacity to interact with other groups and agencies. This basic foundation allowed these groups to take on a more proactive and successful role in forest management when opportunities appeared. The communities had to experiment over time with how to adapt these political governance institutions to the very different demands of enterprise management. In the process, they had to learn how to balance the demands for democratic governance with the need for hierarchical decision-making in an enterprise [32].

In the extractive reserves of Brazil and the TCOs of Bolivia, the reform process was initiated more recently and has been very successful in demarcating property rights for traditionally forest dependent people, placing huge territories under the control of rural people. However, the policy mechanisms that create these properties lack some key elements that have complicated the emergence of strong multi-scaled governance institutions. In both Brazil and Bolivia, the enormous properties created tend to contain multiple communities, sometimes dozens or even hundreds. While the property legislation recognizes the rights of residents to continue traditional livelihoods and resource use practices, the community level institutional sub-units that pattern resource use by resident households through customary rules for access and management are not legally recognized, delineated or provided any specific official authority. These governance institutions do exist and are salient entities for local people and could develop into more formal local governance institutions to link with higher levels forming a strong multi-scaled governance system. This is particularly the case since the state allows groups to self organize for internal governance of these properties. However, there is no assurance that this will happen and, in fact, rapid economic change and external vested interests could work against such development and undercut local authority and leaders.

Grouping multiple communities that are dispersed over vast areas under the same communal property right introduces a level of complexity that is a challenge for institutional development. Community groups dispersed in forest landscapes may have limited contact or engagement with neighboring communities, or if they do, the relationships mix both cooperative and conflictive elements. Although in both countries community level stakeholders had united in grassroots social movements to press for recognition of property rights, once the larger property boundaries were demarcated, they had less incentive to collaborate. Property rights legislation in both countries does address governance, but usually focusing on institutions intended for the whole territory. The results are, initially at least, weak institutions facing complex challenges in governing huge areas, with no direct link to local production or resource use decisions. In the Brazilian extractive reserves, the management council needs to develop management plans for the entire RESEX to provide official sanction to resource use under strict conservation rules and to allow innovations like the introduction 
of legal timber management. However, the councils can have competing interests and participation is not limited to just residents or their representatives. This is in notable contrast to the Mexican case where a community with well defined members has ownership of a clearly demarcated territory which is usually of a more manageable size, and can feasibly be patrolled and controlled by the community.

Unlike Mexico, in TCOs, the properties are titled to representative indigenous organizations, not to individual indigenous residents. Some indigenous organizations are very cohesive and responsive to their constituencies but not all are. In many cases these collective groups formed as activist organizations to press for property rights but were not organized for territorial administration and management. More so, these organizations hold the titles over huge areas but are actually granted little authority by the state within them. Local governance authority is held by municipal governments and the constellations of village level and neighborhood level organizations that make up the decentralized system in Bolivia. In some cases there is close correspondence between indigenous and municipal authority, but it is typical that TCOs are superimposed across several municipalities and include substantial non-indigenous populations. As a result, governance authority becomes diffuse or divided.

Finally, in Brazil and Bolivia property rights and forest management rights were granted in relatively quick succession. Consequently, local governance institutions have had little time to learn and adapt. Efforts to promote CFM have focused more on forest policy and introduced technical models and placed less emphasis on building institutional governance capacity. Community forestry development has produced highly subsidized pilot initiatives that have had little impact on the vast majority of rural people who could not adopt the systems and continue to work informally. One reason is that demanding technical requirements translate into high start-up and operational costs for compliance with regulations, and create barriers that are difficult for most communities without external funding. Nonetheless, community groups are experimenting with CFM to improve use and control over their territories. In the Verde para Sempre RESEX in Brazil, some communities are negotiating to gain recognition for the arrangements and institutions they had developed earlier to control use of local resources. In Guarayos, communities have formed CFEs to buttress their village level territorial organization. Some community level groups were able to use the opportunity to develop forest management plans to gain recognition of their control over local forests, but not all communities succeeded.

\subsection{Recommendations}

There are several key lessons that can be drawn from the case studies of these three countries that are applicable to REDD+ planners to support necessary local governance institutions.

Formalizing forest property access rights of local forest inhabitants is the necessary first step to introduce extensive landscapes into REDD+ programs. Planners of REDD+ programs who choose to include a CFM element should focus on design principles found in successful communal resource management systems [44]. In other words there should be clear boundaries, defined membership, legal recognition of local governance, local rule making authority, and shared interest among members. Efforts to support administrative governance should start at the basic level of production units where people have vested interests. However, local heterogeneity must be taken into consideration to guarantee that legitimate owners are beneficiaries and to mediate competing claims. If communal 
properties combine multiple communities and ethnic groups, efforts should develop the necessary government institutions at relevant scales, adapting customary governance institutions that already exist.

While REDD+ planners may be tempted to develop programs that only cover large areas which could seem more expedient, they should also be attentive to the need to build from the bottom up, if possible using customary patterns of organization (at least as points of departure). However, if institutions are insufficient or weak at the local scale, it is unlikely that structures imposed at a secondary level will work either. To support democratic processes and transparency, REDD+ planners should propose the introduction of templates or frameworks for the development of governance institutions. These templates will better assure that all residents have avenues to participation and that they have defined procedures for taking responsibility and transparently distributing benefits.

REDD planners should expect long periods of learning and adaptation. When REDD programs are introduced it will probably take a medium term time frame of three to five years just to get through the initial stages of institution building. In other words, donors should be prepared to provide 'patient money' that will allow local institutions to emerge, probably through a process of trial and error.

Communities can be effective at conserving and expanding forest cover, generating community-level benefits, and providing governance at appropriate scales. Evidence shows that communities have been effective at reducing deforestation under a variety of governance forms. Community benefits from timber in particular are notable, since it is still the forest product with the highest value and most accessible markets (given adequate transportation networks), and can produce significant economic returns to community forest households, through direct employment, profit-sharing, and investment in community public goods [50]. Local governance institutions with multiple linkages at other scales can augment forest law enforcement efforts. If REDD initiatives provide support or local subsidies to CFM, they can lower costs, and outcompete alternative land uses. This is particularly true since CFEs commonly operate on principles where the profit motive is only one of a suite of management goals [50].

In many areas where CFM is practiced, it would be possible to build on existing institutions. Care would need to be taken to make sure new programs do not undercut successful CFM initiatives (for example by mandating more restrictive rules that complicate local operations). In areas where communities are managing forest resources without official recognition, there is also opportunity to expand REDD programs greatly using relatively simple measures. These mechanisms would entail validating and authorizing existing management systems and thus provide greater security and support for forest managers who lack legal recognition. Expanding CFM into new areas will likely require more extensive training and support programs to develop initiatives and assist community groups as they get started. Having community-level actors managing resources and enforcing compliance themselves will cost less than if this effort were to be conducted by technical professionals or government agencies.

Efforts to support and expand CFM as a REDD mechanism could strengthen rights of local community-level stakeholders and ensure their participation. For that to happen it is necessary to assure the role and authority of local institutions at relevant scales for participants' resource use and the production system. If local level governance does not exist or function, it is difficult if not impossible to establish workable governance frameworks at higher levels that involve local people. An 
additional benefit to focusing on CFM for REDD+ is that the rights and benefits will be dispersed amongst some of the most marginalized people on rural frontiers. Forest people often have little voice in such development processes and explicit efforts to include them are likely to produce more equitable outcomes.

\section{Conclusions}

REDD+ proposals show great promise for creating incentives to slow deforestation and degradation, and to maintain and expand carbon stocks in natural forests. CFM could potentially be adopted as a program component under REDD+ initiatives. There is growing evidence that some type of local forest management have slowed and, in some cases, stopped deforestation and enhanced carbon stocks. CFM has made gains in forest management and simultaneously achieved more equitable outcomes in the distribution of forest incomes, all at a relatively low cost. A key to CFM success is identifying and maintaining working institutional frameworks where they exist and promoting them in forest landscapes where they do not.

REDD planners can learn from factors that have supported successful CFM development, namely facilitating the emergence of governance at multiple scales, starting with strong emphasis on the local scale. While there are a broad variety of CFM systems in the region, we identified some common factors in establishing a foundation for these systems. These include forest tenure rights that enable forest livelihoods and strong multi-scaled governance institutions capable of implementing, maintaining and defending productive forest systems. We also argue that existing forms of forest valuation such as giving timber rights to local communities should become part of the suite of strategies adopted by REDD + architects. Forest carbon markets are likely to be in a disorganized state for some time to come, and will have difficulty in competing with commercial uses such as soybeans in the foreseeable future. For the enormous territories of the Amazon Basin, as well as some other world regions, governance institutions for large areas must be combined with design elements that give some degree of autonomy to local communities, while assuring them of the extensive partnership mechanisms needed to launch new institutions and forest production activities. Given that an increasing portion of the forest land in question is owned, occupied by or used by rural people, these forest-dependent communities will need to play significant roles in REDD+ programs and should be major recipients of benefits generated by such efforts. CFM is one major strategy that can achieve the goals of efficiency, effectiveness and equity while reducing deforestation and degradation.

The multiple benefits and sustainability that can emerge from mature CFM experiences is summed up by Luis Pacheco, the current leader of the Ixtlán CFE from Mexico discussed above and a community member, "We are now integrated from the planting of a seed in the forest to the production of certified furniture from our well-managed forests at the other end. We close the cycle. With all the changes in the world with climate change and deforestation, we think we are working for the future, we don't want the generations that come later to accuse us of just creaming off the best of the forest and not leaving anything for them" [54]. 


\section{References}

1. Moving Ahead with REDD: Issues, Options and Implications; Angelsen, A., Ed.; CIFOR: Bogor, Indonesia, 2008.

2. Realising REDD+: National Strategy and Policy Options; Angelsen, A., Ed.; CIFOR: Bogor, Indonesia, 2009.

3. Berkes, F. Community-based conservation in a globalised world. P. Natl. Acad. Sci. 2007, 104, 15188-15193.

4. Hayes, T.; Persha, L. Nesting local forestry initiatives: Revisiting community forest management in a REDD+ world. Forest Pol. Econ. 2010, 12, 545-553.

5. Duran, E.; Bray, D.B.; Velázquez, A.; Larrazábal, A. Multi-scale forest governance, deforestation, and violence in two regions of Guerrero, Mexico. World Dev. 2011, 39, 611-619.

6. Chhatre, A.; Agrawal, A. Trade-offs and synergies between carbon storage and livelihood benefits from forest commons. P. Natl. Acad. Sci. 2009, 106, 17667-17670.

7. Nepstad, D.; Schwartzman, S.; Bamberger, B.; Santilli, B.; Ray D.; Schlesinger, P.; Lefebvre, P.; Alencar, A.; Prinz, E.; Fiske, G.; Rolla, A. Inhibition of Amazon deforestation and fire by parks and indigenous lands. Conserv. Biol. 2006, 20, 65-73.

8. Dev, O.P.; Yadav, N.P.; Springate-Babinksi, O.; Soussan, J. Impacts of community forestry on livelihoods in the middle hills of Nepal. J. For. Liv. 2003, 31, 64-77.

9. Bray, D.B.; Duran, E.; Ramos, V.H.; Mas, J.F.; Velazquez, A.; McNab, R.B.; Barry, D.; Radachowsky, J. Tropical deforestation, community forests and protected areas in the Maya forest. Ecol. Soc. 2008, 13, 56. Available online: http://www.ecologyandsociety.org/vol13/iss2/art56/ (accessed on 20 October 2010).

10. Sunderlin, W.D.; Hatcher, J.; Liddle, M. From Exclusion to Ownership? Challenges and Opportunities in Advancing Forest Tenure Reform; Rights and Resources Initiative: Washington, DC, USA, 2008.

11. White, A.; Martin, A. Who Owns the World's Forests? Forest Tenure and Public Forests in Transition; Forest Trends: Washington, DC, USA, 2002.

12. Boyce, J.K.; Shelly, B.G. Natural Assets: Democratizing Environmental Ownership; Island Press, Washington, DC, USA, 2003.

13. The Community Forests of Mexico: Managing for Sustainable Landscapes; Bray, D.B., Merino-Pérez, L., Barry, D., Eds.; University of Texas Press: Austin, TX, USA, 2005.

14. Benneker, C. Dealing with the State, the Market and NGOs: The Impact of Institutions on the Constitution and Performance of Community Forest Enterprises (CFE) in the Lowlands of Bolivia; PhD Thesis; Wageningen University: Wageningen, The Netherlands, 2008.

15. Taylor, P.L. Conservation, community, and culture? New organisational challenges of community forest concessions in the Maya Biosphere Reserve of Guatemala. J. Rural. Stud. 2010, 26, 173-184.

16. Kaufmann, D.; Kraay, A.; Zoido-Lobatón, P. Governance Matters; Policy Research Working Paper 2196; World Bank: Washington, DC, USA, 1999.

17. Andersson, K. Who talks with whom? The role of repeated interactions in decentralized forest governance. World Dev. 2003, 32, 233-249. 
18. Agrawal, A.; Chhatre, A. Explaining Success on the Commons: Community Forest Governance in the Indian Himalaya. World Dev. 2006, 34, 149-166.

19. Carley, M.; Christie, I. Managing Sustainable Development; Earthscan Publications: London, UK, 1992.

20. Adger, W.N.; Brown, K.; Tompkins, E.L. The political economy of cross-scale networks in resource co-management. Ecol. Soc. 2005, 10, 9. Available online: http://www.ecologyandsociety.org/vol10/iss2/art9/ (accessed on 20 December 2010).

21. UNFCC. Ad hoc Working Group on Long-Term Cooperative Action under the Convention, Fifth Session; UNFCC: Bonn, Germany, 2009. Available online: http://unfccc.int/resource/docs/ 2009/awglca5/eng/04p02.pdf (accessed on 3/28/2011).

22. Dahal, G.R.; Larson, A.M.; Pacheco, P. Outcomes of reform for livelihoods, forest condition, and equity. In Forests for People: Community Rights and Forest Tenure Reforms; Larson, A.M., Barry, D., Dahal, G.R., Colfer, C.J.P., Eds.; Earthscan: London, UK, 2010.

23. Angelsen, A.; Wertz-Kanounnikoff, S. What are the key design issues for REDD and the criteria for assessing options? In Moving Ahead with REDD: Issues, Options and Implications; Angelsen, A., Ed.; CIFOR: Bogor, Indonesia, 2008; pp. 11- 21.

24. Molnar, A.; Scherr, S.J.; Khare, A. Who Conserves the World's Forests? A New Assessment of Conservation and Investment Trends; Forest Trends and Ecoagriculture Partners: Washington, DC, USA, 2004.

25. Geist, H.J.; Lambin, E.F. What Drives Tropical Deforestation? A Meta-Analysis of Proximate and Underlying Causes of Deforestation Based on Subnational Case Study Evidence; LUCC Report Series 4; International Human Dimensions Programme on Global Environmental Change (IHDP): Louvain-la-Neuve, Belgium, 2001.

26. Rudel, T.K. Tropical Forests: Regional Paths of Destruction and Regeneration in the Late Twentieth Century; Columbia University Press: New York, NY, USA, 2005.

27. Chomitz, K. At Loggerheads: Agricultural Expansion, Poverty Reduction, and Environment in the Tropical Forests; World Bank: Washington, DC, USA, 2008.

28. Börner, J.; Wunder, S. Paying for avoided deforestation in the Brazilian Amazon: from cost assessment to scheme design. Int. For. Rev. 2008, 10, 496-511.

29. Wunder, S. The efficiency of payments for environmental services in tropical conservation. Conserv. Biol. 2007, 21, 48-58.

30. Ostrom, E.; Janssen, M.A.; Anderies, J.M. Going beyond panaceas. P. Natl. Acad. Sci. 2007, 104, 15176-15178.

31. Phelps, J.; Webb, E.L; Agrawal, A. Does REDD+ threaten to recentralize forest governance? Science 2010, 328, 312-313.

32. Bray, D.B.; Antinori, C.; Torres-Rojo, J.M. The Mexican model of community forest management: the role of agrarian policy, forest policy, and entrepreneurial organisation. Forest Pol. Econ. 2006, 8, 470-484.

33. Cronkleton, P.; Albornoz, M.A. Forestería comunitaria en Bolivia: abriendo horizontes para nuevos actores. In Memória: forum sobre florestas, gestão e desenvolvimento, Belém; CIFOR: Belém, Brazil, 2003; pp. 82-102. 
34. Cronkleton, P.; Pacheco, P.; Ibarguen, I.; Albornoz, M.A. Reformas en la tenencia de la tierra y los bosques: La gestión comunal en las tierras bajas de Bolivia; CIFOR/CEDLA: La Paz, Bolivia, 2009.

35. IBAMA. Lista das unidades de conservação federais, 2009. Available online: http://www.ibama.gov.br (accessed on 25 July 2010).

36. Hayes, T. Parks, people and forest protection: An institutional assessment of the effectiveness of protected areas. World Dev. 2006, 34, 2065-2075.

37. Ruiz-Pérez, M.; Almeida, M.; Dewi, S.; Lozano Costa, E.M.; Ciavatta Pantoja, M.; Puntodewo, A.; de Arruda Postigo A.; Goulart de Andrade, A. Conservation and development in Amazonian extractive reserves: The case of Alto Juruá. Ambio. 2005, 34, 218-223.

38. Soares-Filho, B.S.; Nepstad, D.C.; Curran, L.M.; Coutinho Cerqueira, G.; Garcia, R.A.; Azevedo Ramos, C.; Voll, E.; McDonald, A.; Lefebvre, P.; Schlesinger, P. Modeling conservation in the Amazon Basin. Nature 2006, 440, 520-523.

39. Oliviera, P.J.C.; Asner, G.P.; Knapp, D.E.; Almeyda, A.; Galvan-Gildemeister, R.; Keene, S.; Raybin, R.F.; Smith, R.C. Land-use allocation protects the Peruvian Amazon. Science 1997, 317, 1233-1236.

40. Gomez-Mendoza, L.; Vega-Peña, E.; Ramírez, M.I.; Placio-Prieto; J.P.; Galicia, L. Projecting land-use change processes in the Sierra Norte of Oaxaca, Mexico. Appl. Geogr. 2006, 26, 276-290.

41. Hayes, T.M. Does tenure matter? A comparative analysis of agricultural expansion in the Mosquitia forest corridor. Hum. Ecol. 2007, 35, 733-747.

42. Stocks, A.; McMahan, B.; Taber, P. Indigenous, colonist, and government impacts on Nicaragua's Bosawas reserve. Conserv. Biol. 2007, 21, 1495-1506.

43. Agrawal, A.; Angelsen, A. Using community forestry management to achieve REDD+ goals. In Realising REDD+: National Strategy and Policy Options; Angelsen A., Ed.; CIFOR: Bogor, Indonesia, 2009; pp. 201-211.

44. Ostrom, E. Governing the Commons: the Evolution of Institutions for Collective Action; Cambridge University Press: London, UK, 1990.

45. Sunderlin, W.; Larson, A.; Cronkleton, P. Forest tenure rights and REDD+: From inertia to policy solutions. In Realizing REDD+: National Strategy and Policy Options; Angelsen, A., Ed.; CIFOR: Bogor, Indonesia, 2009.

46. Luttrell, C.; Schreckenberg, K.; Peskett, L. The Implications of Carbon Financing for Pro-Poor Community Forestry; Forestry Briefing 14; Overseas Development Institute: London, UK, 2007.

47. Larson, A.; Barry, D.; Cronkleton, P.; Pacheco, P. Tenure Rights and Beyond: Community Access to Forest Resources in Latin America; CIFOR Occasional Paper No. 50; CIFOR: Bogor, Indonesia, 2008.

48. Forests for People: Community Rights and Forest Tenure Reform; Larson, A., Barry, D., Dahal, G.R., Eds.; Earthscan: London, UK, 2010.

49. Cronkleton, P.; Taylor, P.; Barry, D.; Stone-Jovicich, S.; Schmink, M. Environmental Governance and the Emergence of Forest-Based Social Movements; CIFOR Occasional Paper 49; CIFOR: Bogor, Indonesia, 2008.

50. Antinori, C.; Bray, D.B. Community forest enterprises as entrepreneurial firms: Economic and institutional perspectives from Mexico. World Dev. 2005, 33, 1529-1543. 
51. Bray, D.B.; Merino-Pérez, L. La Experiencia de las Comunidades Forestales en México: Veinticinco Años de Silvicultura y Construcción de Empresas Comunitarias; Instituto Nacional de Ecología (INI-SEMARNAT): Ciudad de México, Mexico, 2004.

52. Bray, D.B.; Durán Medina, E.; Merino Pérez, L.; Torres Rojo, J.M.; Velázquez Montes, A. Nueva Evidencia: Los Bosques Comunitarios de México Protegen el Ambiente, Disminuyen la Pobreza y Promueven la Paz Social; Agrupación Sierra Madre/Consejo Civil Mexicano para la Silvicultura Sostenible: Ciudad de México, Mexico, 2007.

53. Mathews, A. Building the town in the country: official understandings of fire, logging and biodiversity in Oaxaca, Mexico, 1926-2004. Soc. Anth. 2006, 14, 335-359.

54. Bray, D.B. Capitalism meets common property. Americas Q. 2010, Winter, 31-35.

55. SEMARNAT. Vision de México sobre REDD+; Secretaria de Medio Ambiente y Recursos Naturales: Mexico City, Mexico, 2010.

56. Bray, D.B.; Ellis, E.A.; Armijo-Canto, N.; Beck, C.T. The institutional drivers of sustainable landscapes: a case study of the 'Mayan Zone' in Quintana Roo, Mexico. Land Use Pol. 2004, 21, 333-346.

57. Gordon, J.E. The role of science in NGO mediated conservation: insights from a biodiversity hotspot in Mexico. Environ. Sci. Pol. 2006, 9, 547-554.

58. Robson, J.E. Local approaches to biodiversity conservation: lessons from Oaxaca, southern Mexico. Int. J. Sust. Dev. 2007, 10, 267-286.

59. Schwartzman, S. Deforestation and popular resistance in Acre: From local social movements to global network. Centennial Rev. 1991, 35, 397-422.

60. Schmink, M.; Wood, C. Contested Frontiers in Amazonia; Columbia University Press: New York, NY, USA, 1992.

61. Allegretti, M.H.. Reservas extrativistas: Parâmetros para uma política de desenvolvimento sustentável na Amazônia. In $O$ destino da floresta: Reservas Extrativistas e desenvolvimento sustentável na Amazônia; Arnt, R., Ed.; Relume-Dumará: Rio de Janeiro, Brazil, 1994; pp. 17-47.

62. Medina, G.; Pokorny, B. Avaliação Financeira do Manejo Florestal Comunitário; IBAMA: Manaus, Brasil, 2009.

63. Medina, G; Pokorny, B; Campbell, B. Community forest management for timber extraction in the Amazon frontier. Int. For. Rev. 2009, 11. 408-420.

64. Stearman, A. The highland migrant in lowland Bolivia; multiple resource migration and the horizontal archipelago. Hum. Organ. 1978, 37, 180-185.

65. Thiele, G. The displacement of Peasant Settlers in the Amazon: The case of Santa Cruz, Bolivia. Hum. Organ. 1995, 54, 273-282.

66. CIDOB/CPTI. 10 años San-TCO: La lucha por los derechos territoriales indígenas de tierras bajas Bolivia; Confederación de pueblos indígenas de Bolivia CIDOB, Centro de Planificación Territorial Indígena, CPTI: Santa Cruz de la Sierra, Bolivia, 2008.

(C) 2011 by the authors; licensee MDPI, Basel, Switzerland. This article is an open access article distributed under the terms and conditions of the Creative Commons Attribution license (http://creativecommons.org/licenses/by/3.0/). 